\title{
THE USE OF DISCARDED DATE PALM FOR BIOETHANOL PRODUCTION AND FEEDING LACTATING BUFFALOES
}

\author{
Sabbah M. Allam ${ }^{1}$; A.M. Ali ${ }^{1}$; M.M.Bendary ${ }^{2}$; A.A. El-Bana ${ }^{3}$;.M.El-Nahrawy ${ }^{2}$ and \\ Hala M. Farrage ${ }^{3}$ \\ IAnimal Production Dept., Faculty of Agriculture, Cairo University, Giza, Egypt. \\ ${ }^{2}$ Animal Production Res. Institute, Agriculture. Res. Center, Ministry of Agric., Dokki, Giza, Egypt. \\ ${ }^{3}$ Central Laboratory of Date Palm Research, Agriculture Res. Center, Ministry of Agric., Dokki, Giza, \\ Egypt.
}

\section{SUMMARY}

$\mathrm{T}$ o evaluate the chemical composition, nutritive value and economic efficiency of ethanol production from discarded dates palm (DDP). Tested DDP was collected from New Valley region farms after harvesting, sundried and crashed. The $1^{\text {st }}$ part of crashed unfermented discarded date palm (UFDDP) was used as it is to evaluate its nutritive value; while the $2^{\text {nd }}$ part was used to produce ethanol and the by-product of ethanol production, fermented discarded date palm (FDDP), was evaluated. Three digestibility trials were carried out using nine rams. Clover hay $(\mathrm{CH})$ was used as a basal ration to investigate digestion coefficients and nutritive values of DDP. Ethanol was produced from four different parts of DDP by-product using yeast (Saccharomyces cerevisiae).

Results showed that UFDDP had the highest DM, OM, EE, NFE and GE contents than those of FDDP, while CP, CF and ash contents had opposite trend. Unfermented discarded date palm (UFDDP) had the highest digestion coefficients $(\mathrm{P}<0.05)$ of OM, EE and NFE, while; FDDP with wheat bran had the highest digestion coefficients of CP and CF. The highest TDN, GE and DE were found for UFDDP, while FDDP recorded the lowest values.

Under experimental fermentation processing conditions, one ton of DDP with wheat bran, DDP flesh, DDP only, Date pits produced on average 224, 283.9, 261, 96.87 liters ethanol/ton, with a total price 4955, 6280, 5773 and 2143 L.E., respectively.

Fifteen lactating buffaloes with average weight of $(550-650 \mathrm{~kg})$ and at their $\left(2^{\text {nd }}\right.$ and $\left.3^{\text {rd }}\right)$ lactating season, were randomly divided into five groups to evaluate the effect of incorporating DDP instead of corn grains in concentrated feed mixture on milk production performance. Five tested rations were offered in three successive experimental periods in complete switch back design. All experimental rations were formulated to contain $26.5 \%$ maize silage, $21.0 \%$ Egyptian clover, $10.0 \%$ rice straw in combination with $42.5 \%$ concentrate feed mixture (CFM) contained either 35\% yellow corn grains (R1) or DDP was used instead of yellow corn grains by $50 \%$ (R2) or $100 \%$ (R3) or FDDP was used instead of yellow corn grains by $50 \%$ (R4) or $100 \%$ (R5). Results indicated that animals fed R1, R2 or R3 showed the best feed efficiency as DM, TDN and DCP, compared with those fed R4 or R5. Meantime, economic efficiency recorded insignificant differences with substituting corn grain by DDP in the $2^{\text {nd }}$ and $3^{\text {rd }}$ rations. On contrast replacement corn grains by FDDP led to decrease the economic efficiency by about 25.98 and $30.39 \%$ for the $4^{\text {th }}$ and $5^{\text {th }}$ rations, respectively. Moreover, substituting corn grains by 50 or $100 \%$ DDP during formulation of CFM led to reduce the price of one ton concentrate by about 8.0 and $16 \%$, respectively.

Results of this study indicated that discarded dates can be incorporated into the rations of ruminant animals replacing all or a part of maize grains imported reverberating both beneficial the national economy to provide an outlet for date sector. Along with it can be used successfully for ethanol production and using the residues after fermentation for feeding animals.

Keywords: Discarded dates palm, fermented discarded dates palm, digestibility, milk production, buffaloes. 


\section{INTRODUCTION}

There is an increase for using grains, especially maize, for biofuel production as energy source for human leading to increase the price of energy source in animal rations, therefore new sources of energy for animals must be found.

Egypt is the first important country in date palm world production which is represented about $17 \%$ of the total world production (FAO, 2012). Whereas, there is about 12.26 million palm trees (different varieties), producing about 1.37 million tons date crop annually (Ministry of Agriculture and Land Reclamation , 2012).Meantime, the quantity of discarded dates is estimated to be about $20 \%$ of dates produced (Belalet al., 1999), which could be used to feed animals with high energy supplements (Mikkiet al., 1986). Date waste is a good source of energy, thus it may be possible to use date waste as an energy source in ruminant rations.

Dates are rich in sugar and the total sugar content depends on the variety and it varies between 60 and $76 \%$ from DM and it is constituted mostly of glucose and fructose. Dates have a low protein concentration (1.5-4\% DM), which depends on the variety (Boudechicheet al., 2008).

The major sugar in dates, glucose and fructose, are present in approximate levels of $44 \%-79 \%$ on dry basis (FAO, 2006), thus making date extracts quite suitable as a feedstock for ethanol production and the residues could be used for ruminants feed. Date fruits can provide $2.67 \mathrm{Mcal} / \mathrm{kg}$ of digestible energy. While, barley grains provides $3.06 \mathrm{Mcal} / \mathrm{kg}$ of digestible energy (Alhomidyet al., 2011). Also, dates can supply $87 \%$ of the digestible energy provided by the same unite mass of traditional feed grain (AlKhateeb and Ali-Dinar, 2001). By-Product of ethanol production from discarded dates may be become more available to livestock feeders.

Research in animal nutrition has shown that feeding sugar is better than feeding starch as the sugar is directly converted into glucose without much nutrient loss (Chamberlain et al., 1993). The concept of feeding sugar by-products was developed on this physiological principle.

The available information in the literature about the inclusion of discarded date in lactating buffalo's rations is very scarce. Most of the studies focused on carcass characteristic and meat quality of goats or sheep (Mahgoubet al., 2005).

Therefore, the main objectives of the present work are to:

1- Investigate the chemical composition and nutritive value of the discarded dates palm before and after ethanol production.

2- Study the economic impact of using discarded dates in lactating buffalo rations on milk production and composition.

\section{MATERIALS AND METHODS}

The current work was carried out at the Entire Central Laboratory For Date Palm Research, MehalletMousa Animal Research Station, Animal Production Research Institute, Ministry of Agriculture and Department of Animal Production, Faculty of Agric., Cairo University.

Discarded dates palm (DDP) including different kinds (dried and semi-dried) and different varieties were collected from the local farms at New Valley region after harvesting and sundried until the moisture content reduced to about $12 \%$ and then, the dried discarded date was crushed after mixing it with wheat bran at the rate of $250 \mathrm{~kg}$ per ton of dates (20\%) to facilitate the crushing process.

The crushed discarded dates palm was divided into two parts. The $1^{\text {st }}$ part was used as it's to evaluate chemical composition and nutritive values, while the $2^{\text {nd }}$ part of crashed unfermented discarded date palm UFDDP was used to study the economic efficiency of using it for producing ethanol and evaluate its byproduct fermented discarded date palm (FDDP) for feeding ruminants.

\section{Ethanol production:}

Overall process of ethanol production in the present study was carried out according to the method described by Mehaia and Cheryan (1991) as follows:

Four tested types of discarded date palm by products were used, the $1^{\text {st }}$ one represented the crashed discarded date palm with wheat bran DDPW used in these study contained $20 \%$ wheat bran, while the $2^{\text {nd }}$ was DDP flesh (DDPF), and the $3^{\text {rd }}$ was discarded date palm only (DDP), while crushed date palm pits (DPP) used as the 4th by products of DDP. Three samples were taken from each kind, each sample one $\mathrm{kg}$. Tap distilled water was added at ratio of 2 parts water to one part dates (by weight) with batch culture yeast Saccaromycescerevisiae, the inoculum was contained 103-104 cells. The mixture was incubated at temperature $28 \pm^{\circ} \mathrm{C}$ via continuous stirring for one week. Samples were filtrated after incubation period using cheese cloth. The residual from DDPW after filtration called fermented discarded date palm 
(FDDP) was used for the nutritive value evaluation, while extract solutions from all discarded dates palm types were used for determination ethanol using GC 10, Ver. 126. After ethanol estimation, the twelve extract solutions were boiled for half hour to evaporate all ethanol produced. The reminded of all extract solutions were inoculated again with the same batch culture and incubated as described previously to ensure that all soluble sugars were fermented. Ethanol was determined again after the second incubation. Total ethanol produced $=1^{\text {st }}+2^{\text {nd }}$ estimation.

\section{Digestibility trials:}

Nine rams were used in indirect digestible trials as mentioned by (Abou-Raya, 1967) for 22 days, 15 days preliminary period and 7 days as collected period. Animals were divided into three groups (3 in each) to fed either clover hay $(\mathrm{CH})$ as basal ration, $\mathrm{CH}$ plus unfermented discarded date palm (UFDDP) or $\mathrm{CH}$ plus FDDP. Ninety percent of ad libtum intake, in preliminary period, was offered for each ram (in 2 meals at 8.00 a.m. and 5.00 p.m.) during the days of collection period. Water was available at all times. Daily fresh feces from each ram was weighed during the collection period and representative samples of each collection was taken and dried in forced air oven at $65^{\circ} \mathrm{C}$ for 48 hours. Dried samples for each ram at the end of collection period were thoroughly mixed, ground and kept for chemical analysis.

Chemical analysis of UFDDP, FDDP, $\mathrm{CH}$ and feces were carried out to determine DM, CP, CF, EE and ash according to the method of A.O.A.C. (1990). While NFE values were calculated by differences.

Gross energy of UFDDP and FDDP samples were determined with an adiabatic bomb calorimeter (Parr instrument Co., Inc., Moline, IL)

Total digestible nutrients (TDN) was calculated according to the classic formula of McDonald et al., (1995), while digestible energy (DE Mcal/kg DM) was calculated according to NRC (1988) the data obtained were subjected to statically analysis according to Snedecor and Cochran, (1982), Differences among treatments means were tested by multiple rang tested of Duncan, (1955).

\section{Lactation trial:}

\section{Experimental Animals:}

Fifteen lactating buffaloes weighed $550-650 \mathrm{~kg}$ and at $2^{\text {nd }}$ to $3^{\text {rd }}$ lactating season were used after 8 weeks of calving. The buffaloes were free from any disease with normal health appearance. A complete switch-back experimental design were used with five treatments and three successive experimental period consisted of 28 days, the first 14 days of each period were considered a transition period followed by 14 days test period, as described by (Lucas, 1956).

The experimental buffaloes were put into three randomly blocks. Each block contained 5 buffaloes every one buffalo from each block was assigned randomly to each experimental ration.

\section{Feeding system and management}

The buffaloes were housed under open sheds and individually fed according to requirement of (APRI, 1997) for lactating buffaloes. Feeding allowances were adjusted weekly according to changes in body weight and milk production. All experimental rations were formulated to contain $26.5 \%$ maize silage, $21.0 \%$ Egyptian clover, $10.0 \%$ rice straw in combination with $42.5 \%$ concentrate feed mixture (CFM) contained ether 35\% yellow corn grains (R1) or DDP was used instead of yellow corn grains by $50 \%$ (R2) or $100 \%$ (R3) or FDDP was used instead of yellow corn grains by $50 \%$ (R4) or $100 \%$ (R5).

Concentrate feed mixture was offered twice daily at 8 a.m. and 4 p.m.; while, corn silage was offered daily at 9 a.m. moreover, fresh Egyptian clover was offered daily at 4 p.m. and rice straw was offered at 8 p.m. Fresh water was offered three times daily; at 7 a.m., 3 p.m. and 8.p.m.

\section{Milk yield and milk composition}

Individually morning and evening milk yields were recorded daily then, milk was adjusted as $7 \%$ fat corrected milk (FCM) using the formula given by Raafat and Saleh (1962) as follows:-

$$
7 \% \mathrm{FCM}=0.265 \times \text { milk yield }+10.5 \times \text { fat yield }
$$

Composite milk samples from consecutive morning and evening samples were taken once every week during the collection period. It was mixed in proportion to yield and analyzed for fat, protein, solids not fat (SNF), total solids (TS) and (ash) by a Milko Scan, Model 133 B. 


\section{Digestibility trials}

Five digestion trails were carried out during $3^{\text {rd }}$ period of the lactating trials using all experimental buffaloes ( 3 animals in each group), to determine the nutrients digestibility and nutritive values of the experimental rations. Fecal rectum samples were collected for six successive days from each animal. Samples of experimental feedstuffs and feces were composted and representative samples were analyzed according A.O.A.C (1990).

Acid insoluble ash (AIA) was used as natural marker (Van Keulen and Young, 1977) and determined in feedstuffs and feces by the method of Schneider and Flatt (1975). Total digestible nutrients (TDN) and digestible crude protein (DCP) were calculated according to the classic formula of (McDonald et al., 1995). While the digestible energy (DE Mcal/kg DM), was calculated according to (NRC, 1988).

\section{Feeding utilization efficiency}

Feeding utilization efficiency was determined as amount of DM, TDN, DE and DCP required for producing $1 \mathrm{~kg} 7 \%$ FCM.

\section{Economic efficiency}

Economic efficiency was calculated as the ratio between the price of $7 \%$ FCM produced and the cost of feeds consumed based on the following prices: Egyptian pound (L.E.) per ton, during years 2011 and 2012; fresh buffaloes milk (4500 L.E/ton, commercial concentrate feed mixture (2200 L.E./ton), fresh Egyptian clover (150 L.E/ton ), maize silage (300 L.E/ton), wheat bran (1200 L.E/ton), maize grain (1750 L.E/ton), rice straw (150 L.E/ton), fermented discarded dates (500 L.E./ton), unfermented discarded dates (760 L.E/ton). However, the prices of one ton of experimental concentrate feed mixtures were CFM2 (2027 L.E/ton), CFM3 (1853 L.E/ton), CFM4 (1983 L.E/ton) and CFM5 (1762 L.E/ton).

$$
\text { Economic efficiency }=\frac{\text { Money input }(\text { price of milk produced })}{\text { Money output }(\text { price of feeds consumed })}
$$

\section{Statistical analysis}

The data obtained were subjected to statistical analysis according to Lucas, (1956) and Snedecor and Cochran, (1982)

Treatment means $=\dot{Y}+Q / 2 n p$

In which $Y$ is the grand mean performance in the experiment, the mean of the original data

$\mathrm{Q}=$ sum of D's for the buffaloes receiving the treatment in the first and third periods minus the sum of the D's for the cows receiving the treatment in the second period

$\mathrm{D}=\mathrm{Y}_{1}-2 \mathrm{Y}_{2}+\mathrm{Y}_{3}$

In which $\mathrm{Y}_{1}, \mathrm{Y}_{2}$ and $\mathrm{Y}_{3}$ represent the performance in periods 1,2 and 3 respectively.

$\mathrm{n}=$ number of buffaloes per treatment sequences,

$\mathrm{p}=$ number of treatments. ANOVA

Using General linear models procedure adapted by SPSS (2088) for user's Guide, with one way

$$
\mathrm{Y}_{\mathrm{ik}}=\mu+\mathrm{F}_{\mathrm{i}}+\mathrm{e}_{\mathrm{ik}}
$$

Where:

$\mathrm{Y}_{\mathrm{ik}}=$ any observed value $\quad \mu=$ the overall mean

$\mathrm{F}_{\mathrm{i}}=$ effect of feed type (1-9) $\quad \mathrm{e}_{\mathrm{ik}}=$ random error

Differences among treatment means were tested by multiple range test of Duncan, (1955).

\section{RESULTS AND DISCUSSION}

Chemical composition and gross energy of experimental feeds are presented in Table (1). Results showed that UFDDP had the highest DM, OM, EE, NFE and GE contents compared with FDDP. While $\mathrm{CP}, \mathrm{CF}$ and ash contents of UFDDP had opposite trend. These results might be due to drainage of the soluble fractions of water soluble carbohydrates and other soluble nutrients during incubation with yeast (Saccharomyces cerevisiae) for producing ethanol. These results are in agreement with findings of Ahmedet al., (1999), Awadallaet al. (2002) and Al-Dobaibet al. (2009). 
Nutritive values as TDN and DCP, digestible energy and gross energy (Table 2) in UFDDP recorded the highest values $(\mathrm{p}<0.05)$ in TDN, GE and DE. While, FDDP recorded the lowest. Meantime, FDDP had significant $(\mathrm{p}<0.05)$ higher DCP value compared with UFDDP. The lowest nutritive value of FDDP mainly due to the great losses of all soluble nutrients especially sugars caused by soaking and fermentation processing during ethanol production from FDDP, the previous results indicated that dates offers a relatively high energy source which is comparable to the concentrate feed.

The nutritive value of UFDDP as TDN in the present study was nearly similar with those obtained by Rashed and Alwash (1976) and Al-Dobaibet al., (2009) who found that the TDN on DM basis of UFDDP ranged between 81.0 and 83.00 .

\section{Ethanol production from discarded date palm by-products:}

Date contains high levels of carbohydrate mostly as monosaccharaides (glucose and fructose 1:1) (Belalet al., 1999). Thus making date extracts quite suitable as a feedstock for fermentation, and converting the sugars into ethanol by Sacchromycescerevisiaeyeast as described byMehaia and Cheryan, (1991).

However, chemical composition of tested DDP by-products was determined to investigate the effect of sugar contents as NFE on the quantity of ethanol produced per ton date by-products.

Chemical composition of date in Table (1) showed that DDPF contained the highest NFE (76.60) followed by DDPW with wheat bran (75.14) while DDP recorded 66.57and date palm pits showed the lowest value (39.98). Such results were mainly associated with or without presence of pits or wheat bran in the tested date palm. Data of ethanol production (Table 3) indicated that, the average value of ethanol produced appeared to be more affected by NFE content of tested DDP by-products. It was noticeable that DDPF contained the highest NFE\% achieved the highest quantity of ethanol (283.9 L/ton) followed by DDP with pits $(261 \mathrm{~L} /$ ton$)$, while the date pits recorded the lowest value of ethanol $(96.87 \mathrm{~L} /$ ton$)$. Meantime, DDP with wheat bran showed $(224.0 \mathrm{~L} / \mathrm{ton})$. These results agree with findings of (Nizaret al., 2007).

\section{Chemical composition of the experimental ingredients and rations:}

Chemical composition of the experimental ingredients and tested rations consumed by lactating buffaloes during experimental period are presented in Table (1). Results indicated that all of the experimental rations had nearly similar values of $\mathrm{OM}, \mathrm{CP} \%, \mathrm{EE} \%$ and ash. While, $\mathrm{CF}$ was the lowest in R1 compared with the other experimental rations. Meantime, NFE decreased from 54.07\% (R1) to $48.95 \%(\mathrm{R} 5)$.

\section{Nutrients digestibility and nutritive value of the experimental rations:}

Average digestion coefficients of experimental rations fed to lactating buffaloes are presented in Table (4). Data indicated that there were no significant $(\mathrm{P}<0.05)$ differences in $\mathrm{OM}$ digestibility among animals fed R2 and R3 compared with those fed R1 being 68.44, 67.83 and $68.80 \%$, respectively. While, R4 and R5 recorded the lowest values of OMD (64.76 and 64.23\%) with significant $(\mathrm{P}<0.05)$ differences compared with R1, R2 and R3. Meantime, R1 and R2 recorded the lowest CF digestibility values 59.55 and 58.9\%, compared with R3, R4 and R5 were $(63.31,68.27$ and $64.78 \%)$, respectively. While, CP digestibility didn't show significant $(\mathrm{P}<0.05)$ differences among $\mathrm{R} 1, \mathrm{R} 3$ and $\mathrm{R} 5$ were $(63.90,64.90$ and $64.83 \%$ ), respectively. while, R2 recorded the highest value $66.48 \%$ and $\mathrm{R} 4$ the lowest $64.04 \%$. While, EE digestibility of R4 and R5 recorded the lowest values; 81.58 and $78.83 \%$, respectively. The lower digestibility coefficients of CF in R1, R2 and R3 may be due the higher NFE which may inhibit the activity of cellulolytic and hemi-cellulolytic, microorganisms, leading to a decrease in the availability and utilization of $\mathrm{CF}$ in the rumen and could have adverse effects on the digestibility coefficients on such nutrients.

The nutritive values of the experimental rations in terms of TDN, DE, and DCP on DM basis are illustrated in Table (4). It could be noticed that rations contained either yellow corn or UFDDP (R1, R2 and R3) had the highest values of TDN and there were no significant $(\mathrm{P}<0.05)$ differences in TDN and DE among these rations. While, R4 and R5 which contained FDDP recorded the lowest significantly $(p<0.05)$ values of TDN and DE. Meantime, all experimental rations showed nearly similar DCP. This result agree with the findings of El-Gasimet al., 1995, that dietary inclusion of date pits significantly improved the feed utilization of sheep.

Many reasons may have been considered responsible for the superiority of nutrients digestibility and nutritive values of R1, R2 and R3 which contained either yellow corn or UFDDP, such as differences in the chemical composition of the experimental ingredients especially fermented and unfermented DDP. 
Moreover, inclusion of UFDDP in R2 and R3 may be caused other beneficial effects (formulated balanced rations adequate amounts of nutrients, minerals and vitamins).

Meantime, the lowest nutritive value of R4 and R5 which contained FDDP mainly due to the great losses of all soluble nutrients especially sugars caused by soaking and fermentation processing during ethanol production from FDDP.

Generally, the present nutritive values are mainly associated with the chemical composition and proportion of the experimental feedstuffs, in particular of UFDDP and FDDP.

\section{Feed intake and feed efficiency:}

Data in Table (5) showed that the average daily intake of experimental feeds on DM basis by experimental lactating buffaloes were nearly similar for the different groups. The absence of significant differences of feed intake may be due to that rations were offered to experimental buffaloes in restricted amounts according to their requirements and calculated nutritive values of experimental feedstuffs. Results obtained are in agreement with the findings of Allamet al., 1997, that no significant differences $(\mathrm{P}<0.05)$ were detected in daily DM intake per $100 \mathrm{BW}$ among lactating Friesian cow fed different rations contained different ratio of yellow corn and date seeds. The same trend were reported by Mahgoub, 2001, that no significant differences $(\mathrm{P}<0.05)$ were detected in the daily DM intake among lactating buffaloes fed different rations of concentrate mixtures and date seeds. The highest significant $(\mathrm{P}<0.05)$ averages daily intake of TDN and DE were observed with buffaloes fed R1, R2 and R3. While, the lowest values were recorded with buffaloes fed R4 or R5. These results may be attributed to the higher TDN and DE of yellow corn and UFDDP containing rations as the results of improving digestibility of most nutrients of these rations as shown in Table (4).

In respect of DCP intake, buffalo fed either R1, R2, R3 and R4 consumed nearly similar and significant $(\mathrm{P}<0.05)$ lower amounts of DCP than those fed $\mathrm{R} 5$.

Feed efficiency expressed as $\mathrm{kg}$ of DMI, TDN and DCP kg required for producing one $\mathrm{kg} 7 \% \mathrm{FCM}$ is presented in Table (5). It could be observed that lactating buffaloes fed R1, R2 or R3 recorded the best feed efficiency as DM, TDN or DCP compared with those fed R4 or R5. This result might be due to the higher milk production for these groups.

\section{Milk production and composition:}

Data of average 7\% FCM for buffaloes fed different rations in Table (6) indicated that there was insignificant $(\mathrm{P}<0.05)$ decrease in 7\% FCM for buffaloes fed R2 compared with those fed R1 but the other rations significantly $(\mathrm{P}<0.05)$ decreased the amount of FCM by 10,31 and $39 \%$ for R3, R4 and R5, respectively compared with $\mathrm{R} 1$. There were insignificant $(\mathrm{P}<0.05)$ differences between the two levels of replacement for each type of DDP in FCM. These results are in agreement with the findings of AlDobaibet al., 2009, that feeding iso-nitrogenous rations including a reasonable dose of discarded dates had no negative effects on milk yield and composition of Aradi goats. The same trend was observed byAllamet al., 1997 andMahgoub, 2001.

The lowest milk production for buffaloes fed R4 or R5 might be attributed to the lowest content of TDN\% and DE in these rations as shown in Table (4). Meanwhile, the requirement of the expected production of tested buffaloes fed R4 and R5 did not cover by giving the experimental rations containing different percentage of FDDP. Data of chemical composition of milk are presented in Table (6) indicated that the average fat percentage ranged from 5.64 to $7.45 \%$. Significant differences $(\mathrm{P}<0.05)$ in fat percentage were existed between $\mathrm{R} 1$ and other groups. There were no significant $(\mathrm{P}<0.05)$ differences between groups fed R2 and R3 also, between R3 and R4 in fat percentage.

The highest milk protein value was observed with buffaloes fed R1 followed by those fed R2; while buffaloes fed R5 recorded the lowest values, and the intermediate values of protein were recorded with buffaloes fed either R3 or R4. These results are in agreement with thoseobtained by Allamet al., 1997, and Mahgoub, 2001. Results indicated that there was no significant $(\mathrm{P}<0.05)$ difference among groups for milk lactose. These results are in agreement with those of Allamet al., 1997, and Mahgoub,2001.Concerning total solids (TS) content in milk results indicated that there was a significant $(\mathrm{P}<0.05)$ decrease when buffaloes fed R2, R3, R4 or R5 compared with those fed R1. There were no significant $(\mathrm{P}<0.05)$ differences in TS content among buffaloes fed R2, R3 or R4. The highest TS for R1 group might be due to the higher fat and protein content of milk produced in this group.The present milk composition in present study are within normal range of milk composition in buffaloes milk which was obtained by El-Aidy ,2003, and Bendaryet al., 2006. 


\section{Economic efficiency:}

Economic efficiency of feeding lactating buffaloes on the experimental rations in Table (7) indicated that economic efficiency as the ratio between prices of 7\% FCM produced plus the additional input for ethanol production for R4 and R5/cost of feed intake was insignificant among R1, R2 or R3. And among $\mathrm{R} 1, \mathrm{R} 3$ and R5 On contrast, feeding buffaloes R4 showed significant decrease $(\mathrm{P}<0.05)$ of economic efficiency compared with the control ration $\mathrm{R} 1$.

It could be concluded that substituting corn grains by 50 or $100 \%$ UFDDP during the formulation of FCM led to reducing the price of one ton from concentrate by about 8 and $16 \%$, respectively. Meantime, FDDP need more research to evident which portion with which additive can replace corn and to be used as a source of energy for animal feed.

\section{REFFRENCES}

Abou-Raya, A. K (1967). Animal and Poultry nutrition $1^{\text {st }}$ Ed, (Text book in arbic) Dar El-Marrf, Cairo, Egypt.

A.O.A.C. (1990).Association of official analytical chemists.Official methods of analysis (13 $\left.{ }^{\text {th }} \mathrm{Ed}\right)$ Washington, D. C., USA.

Ahmed, M.; S., Aziza; M. Abdou and M.R. Hammad (1999). Using date seeds in fattening rations for Friesian calves. Egypt. J. Nutrition and Feeds (Special Issue): 189-198.

Al-Dobaib, S.N.; M.A. Mehaia and M.H. Khalil (2009). Effect of feeding discarded dates on milk yield and composition of Aradi goats. Small Ruminant Research 81, 167-170.

Alhomidy, S. N.; S. Basmaeil; A. n. Al-Owaimer; A. M. El-Waziry and Koohmaraie (2011).Effect of feeding different amounts of discarded dates on growth and efficiency of digestion in sheep. Australian Journal of Basic Applied Sciences, 5(3): 636-640.

Al-khateeb, A.A. and H.M. Ali-Dinar (2001).Date palm (phoenix dactylifera L.) production and research in Kingdom of Saudi Arabia.The date palm international symposium, Windhoek, Nambia.

Allam, S.M.; M.A. Hanafy; I.A. Gamaa and A.M.Abdou(1997).Effect of ammoniation on date seeds utilization in dairy rations. Egypt. J. Nutrition and feeds (special Issue) 201-210.

Animal Production Research Institute, A.P.R.I. (1997).Animal Nutrition.Scientifically and Practically.1st Ed. Anim. Res. Inst. Agric. Rese.Cent, Ministry of Agric. Dokki, Giza, Egypt (In Arabic).

Awadalla, M.; Y.A. Maareck; M.I. Mohamed and M.S. Faraghaly (2002). Response to partial replacement of yellow corn in Rahmani lambs rations with ground date seeds on growth rate, digestion coefficients, rumen fermentation and carcass trates. Egyptian Journal of Nutrition and Feeds, 5 (2): $139-154$.

Belal, I.E.H.; M.S Al-Jasser; I.A. Mustafa and M.N. Al-Dosari (1999). Evaluation of date-feed ingredients mixes. Animal Feed Science Technology, 81:29-298.

Bendary, M.M.; G.H.A. Ghanem, and H.M. Gaafar (2006).Utilization of rice straw for feeding ruminants. 2-Productive performance of lactating buffaloes fed rice straw silage. J. Agric. Sci. Mansora Univ., (8): 5025-5038.

Boudechiche, L.; A. Araba and R. Ouzrout (2008).Study of chemical composition of date wastes and main common varieties of low market value, for use in animal feed.Livest. Res. Rural Dev., 20 (6): 82.

Chamberlain D.G.; S. Robetson and S.J.J. Chong (1993). Sugar versus starch as supplement to grass silage: effect of rumen fermentation and the supply of microbial protein to the same intestine. Estimated from the urinary extraction of purine derivative, in sheep. J. Sci. food. Agric., 63: 184-194.

Duncan, D.B. (1955).Multiple ranges and multiple F-tests. Biometrics, 11:1.

El-Aidy, A.A.A. (2003).Effect of maize silage usage with berseem on the production and reproduction performance of dairy buffaloes M.Sc. thesis, Fac. Agric. Ain Shams Univ., Egypt.

El-Gasim E.A.; Y.A. Al-Yousef and A.M. Humeida (1995).Possible hormonal activity of date pits and flesh fed to meat animals. Food Chem., 52, 149-152.

FAO (2006).Food and Agriculture Organization of the United Nations. The date of world fisheries and aquaculture.Rome, FAO Fisheries Technical Paper 500; 145 pp.

FAO (2012).Food and Agriculture Organization of the United Nations. FAO Agriculture Services Bulletin No. 101.

Lucas, H.L. (1956). Switch-back trial for more than two treatments, J. Dairy Sci., 99-146.

Mahgoub, A.E.A. (2001).Effect of feeding Egyptian buffaloes with palm kernel meal on some productive traits.M. Sc. Thesis, Fac. of Agric; Mania Univ. 
Mahgoub O; I.T. Kadim; E.H. Johnson; A. Srikandakumar and A.M. Al-Saqri (2005).The use of a concentrate containing Meskit (ProsopisJuliflora) Pods and date palm by-products to replace commercial concentrate in diets of Omani sheep. Animal feed Science and Technology, 120, 33-41.

Mehaia M.A.A and M. Cheryan (1991).Fermentation of date extracts to ethanol and vinegar in batch continuous membrane reactors. Enzyme Microb. Technol., 13: 257-261.

Ministry of Agriculture and Land Reclamation (2012).Economic affairs sector. Head of the sector, Cairo Egypt.

McDonald, P.; A.M. Edwards;G.F.D. Greenhalgh and C.A. Morgan (1995).Animal Nutrition. 5th Ed., Copyright licensing LTD., London.

Mikki, M.S.; A.H. Hegazi; A.A. Abdel-Aziz and S.M. Taisan (1986).Suitability of major Saudi date cultivars for commercial handling and packing. In: Proceeding of the 2nd symposium on the Date palm in Saudi Arabia King, Faisal Univ. Al-Hassa. KSA.pp 9-23.

Nizar, C.; F. Ali.; M. Abdesalam and S. Maheur (2007).Chemical composition of flesh and the pits of date palm fruit and Radical Scavenging activity of their extracts. Pakistan Journal of Biological Sciences, 10(13): 2202-2207.

NRC, (1988).Nutrient requirements of dairy cattle. $6^{\text {th }}$ Rev Ed. National Research Council. Acad. Sic, Washington, D. C.

NRC, (2001).Nutrient requirements of dairy cattle. $6^{\text {th }}$ Rev Ed. National Research Council. Acad. Sic, Washington, D. C.

Raafat, N.A. and M.S. Saleh (1962).Two formulas for the conversion of cow's and buffalo's milk of different fat percentage into milk of standard fat percentage, proceeding of the 1 st Anim. Prod. Conference at Minia: 203.

Rashed, N.H. and A.H. Alwash (1976). The effect of proportion of date stones in the diet on its digestion and fermentation in the sheep rumen. Iraqe J. Agric. Sci., 10:51.

Schneider, B.H. and W.P. Flatt, (1975).The evaluation of feeds through digestibility experiments. (Book) pp. xxiii + 423pp, ISBN 0-8203-0378-X, Record Number19761431484.

Snedecor, G.W. and W.C. Cochran (1982).Statistical methods (7th Ed) The Iowa Univ. Press Ames. Iowa. USA.

SPSS (2008).Statistical package for Social Sciences, statistics for windows, version 17.0.Released 2008. Chicago, U.S.A.: SPSS inc.

Van Keulen, J. and Young, B.A. (1977).Evaluation of acid insoluble ash as a natural marker in ruminant digestibility studies. J. Animal. Sci., 44:282-287.

Table (1). Chemical composition of ingredients and experimental rations (on DM basis).

\begin{tabular}{|c|c|c|c|c|c|c|}
\hline \multirow{2}{*}{ Item } & \multicolumn{6}{|c|}{ Chemical composition, \% } \\
\hline & $\mathrm{OM}$ & $\mathrm{CP}$ & $\mathrm{EE}$ & $\mathrm{CF}$ & NFE & Ash \\
\hline \multicolumn{7}{|l|}{ Ingredients, } \\
\hline $\begin{array}{l}\text { UFDDP } \\
\text { FDDP }\end{array}$ & $\begin{array}{l}96.03 \\
92.12\end{array}$ & $\begin{array}{c}8.69 \\
14.66\end{array}$ & $\begin{array}{l}3.10 \\
2.10\end{array}$ & $\begin{array}{l}10.00 \\
33.75\end{array}$ & $\begin{array}{l}75.14 \\
41.61\end{array}$ & $\begin{array}{l}3.91 \\
7.88\end{array}$ \\
\hline DDPF & 97.50 & 6.31 & 4.92 & 9.66 & 76.61 & 2.50 \\
\hline DDP & 94.32 & 8.91 & 5.42 & 15.01 & 64.98 & 5.68 \\
\hline DPP & 90.50 & 7.17 & 6.21 & 37.14 & 39.98 & 9.50 \\
\hline $\mathrm{CH}$ & 89.30 & 14.10 & 2.50 & 28.90 & 43.80 & 10.70 \\
\hline Egyptian clover & 87.91 & 15.55 & 3.45 & 26.10 & 42.81 & 12.09 \\
\hline Corn grains & 98.69 & 8.58 & 4.03 & 1.79 & 84.29 & 1.31 \\
\hline Maize silage & 93.89 & 8.54 & 2.99 & 25.45 & 56.91 & 6.11 \\
\hline Rice straw & 83.86 & 2.56 & 1.80 & 32.44 & 47.06 & 16.14 \\
\hline \multicolumn{7}{|c|}{ Experimental rations, } \\
\hline $\mathrm{R} 1$ & 90.55 & 12.83 & 3.04 & 20.61 & 54.07 & 9.45 \\
\hline $\mathrm{R} 2$ & 90.36 & 12.83 & 3.49 & 21.61 & 52.88 & 9.64 \\
\hline $\mathrm{R} 3$ & 90.16 & 12.39 & 3.36 & 21.83 & 53.58 & 9.84 \\
\hline $\mathrm{R} 4$ & 90.15 & 12.72 & 3.37 & 22.53 & 51.53 & 9.85 \\
\hline R5 & 89.73 & 13.06 & 3.24 & 24.48 & 48.95 & 10.27 \\
\hline
\end{tabular}

UFDDP: Unfermented discarded date palm+ wheat bran; FDDP: Fermented discarded date palm+ wheat bran; DDPF: Discarded date palm flesh; DDP: Discarded date palm only; DPP: Date palm pits; CH: clover hay; R1: ration contained $35 \%$ corn grains in concentrated feed mixture; R2: ration contained $17.5 \%$ corn grains plus $17.5 \%$ UFDDP in concentrated feed mixture; R3: ration contained 35\% UFDDP in concentrated feed mixture; R4: ration contained $17.5 \%$ corn grains plus $17.5 \%$ FDDP in concentrated feed mixture; R5: ration contained $35 \%$ FDDP in concentrated feed mixture. 
Table (2). Nutritive values of the experimental discarded date by products.

\begin{tabular}{lccccc}
\hline Item & UFDDP & FDDP & SEM & Sig. & CH \\
\hline TDN \% & 77.57 & 62.03 & 3.66 & $*$ & 56.38 \\
GE Mcal/kg DM & 3.97 & 3.57 & 3.52 & $*$ & - \\
${ }^{*}$ DE Mcal/kg DM & 3.42 & 2.73 & 0.16 & $*$ & 2.48 \\
DCP \% & 6.44 & 11.39 & 1.31 & $*$ & 10.81 \\
\hline
\end{tabular}

UFDDP: Discarded Date Palm. FDDP: Fermented Discarded Date Palm. CH: Clover Hay

${ }^{*} D E($ Kcal $/ \mathrm{kg} \mathrm{DM})=0.04409 \times T D N(N R C, 2001)$.

Table (3). Average values of ethanol production from the different kinds of discarded date by products.

\begin{tabular}{lcccc}
\hline \multirow{2}{*}{ Items } & \multicolumn{3}{c}{ Experimental DDP by-products } \\
\cline { 2 - 5 } & DDPF & DDP & DDPW & DPP \\
\hline Average total liters of ethanol produced/ton & 283.9 & 261 & 224.0 & 96.87 \\
Price of one ton from different DDP products & 820 & 650 & 760 & 450 \\
Price ton/number of liters & 2.9 & 2.5 & 3.39 & 4.65 \\
\hline
\end{tabular}

Table (4). Nutrients digestibility coefficients and nutritive values of the experimental rations.

\begin{tabular}{lcccccc}
\hline Item & R1 & R2 & R3 & R4 & R5 & SEM \\
\hline Digestibility coefficients & & & & & & \\
OM & $68.80^{\mathrm{a}}$ & $68.44^{\mathrm{a}}$ & $67.83^{\mathrm{a}}$ & $64.76^{\mathrm{b}}$ & $64.23^{\mathrm{b}}$ & 0.59 \\
CP & $63.90^{\mathrm{b}}$ & $66.48^{\mathrm{a}}$ & $64.90^{\mathrm{b}}$ & $64.04^{\mathrm{c}}$ & $64.83^{\mathrm{b}}$ & 0.37 \\
EE & $87.12^{\mathrm{a}}$ & $85.90^{\mathrm{a}}$ & $86.28^{\mathrm{a}}$ & $81.58^{\mathrm{b}}$ & $78.83^{\mathrm{c}}$ & 0.93 \\
CF & $59.55^{\mathrm{c}}$ & $58.29^{\mathrm{c}}$ & $63.31^{\mathrm{b}}$ & $68.27^{\mathrm{a}}$ & $64.78^{\mathrm{b}}$ & 1.00 \\
NFE & $72.35^{\mathrm{a}}$ & $71.98^{\mathrm{a}}$ & $69.30^{\mathrm{b}}$ & $62.35^{\mathrm{c}}$ & $62.65^{\mathrm{c}}$ & 1.21 \\
Nutritive values & & & & & & \\
TDN\% & $66.15^{\mathrm{a}}$ & $65.46^{\mathrm{a}}$ & $65.52^{\mathrm{a}}$ & $61.84^{\mathrm{b}}$ & $60.74^{\mathrm{b}}$ & 0.63 \\
DE (Mcal/kg) DM & $2.92^{\mathrm{a}}$ & $2.89^{\mathrm{a}}$ & $2.73^{\mathrm{b}}$ & $2.89^{\mathrm{a}}$ & $2.68^{\mathrm{b}}$ & 0.03 \\
DCP\% & $8.20^{\mathrm{b}}$ & $8.23^{\mathrm{b}}$ & $8.04^{\mathrm{c}}$ & $8.15^{\mathrm{bc}}$ & $8.47^{\mathrm{a}}$ & 0.06 \\
\hline
\end{tabular}

$a, b$ and $c:$ means in the same raw with different superscripts differ significantly $(p<0.05)$.

DE Mcal/kg=0.04409 $\times$ TDN

Table (5). Average daily feed intake (on DM basis) and feed efficiency of experimental rations.

\begin{tabular}{|c|c|c|c|c|c|c|}
\hline \multirow[t]{2}{*}{ Items } & \multicolumn{5}{|c|}{ Experimental rations } & \multirow[b]{2}{*}{ SEM } \\
\hline & R1 & $\mathrm{R} 2$ & R3 & $\mathrm{R} 4$ & R5 & \\
\hline $\begin{array}{l}\text { Dry matter intake, } \mathrm{kg} / \mathrm{h} . / \mathrm{d} \text {., } \\
\text { CFM1 }\end{array}$ & 7.06 & & & & & \\
\hline CFM2 & & 7.04 & & & & \\
\hline CFM3 & & & 6.99 & & & \\
\hline CFM4 & & & & 7.01 & & \\
\hline CFM5 & & & & & 7.0 & \\
\hline Egyptian clover & 4.73 & 4.73 & 4.73 & 4.73 & 4.73 & \\
\hline Maize Silage & 2.85 & 2.85 & 2.85 & 2.85 & 2.85 & \\
\hline Rice Straw & 1.79 & 1.79 & 1.79 & 1.79 & 1.79 & \\
\hline Total DM intake & 16.43 & 16.41 & 16.56 & 16.38 & 16.37 & \\
\hline Total intake as TDN/kg/day & $10.87^{\mathrm{a}}$ & $10.77^{\mathrm{a}}$ & $10.85^{\mathrm{a}}$ & $10.13^{\mathrm{b}}$ & $9.94^{\mathrm{b}}$ & 0.10 \\
\hline DE/Mcal/day & $48.41^{\mathrm{a}}$ & $47.48^{\mathrm{a}}$ & $47.84^{\mathrm{a}}$ & $44.63^{\mathrm{ab}}$ & $43.83^{\mathrm{b}}$ & 0.45 \\
\hline Total intake as DCP/kg/day & $1.35^{\mathrm{b}}$ & $1.35^{\mathrm{b}}$ & $1.33^{\mathrm{b}}$ & $1.35^{\mathrm{b}}$ & $1.39^{\mathrm{a}}$ & 0.01 \\
\hline Feed efficiency, & & & & & & \\
\hline $\mathrm{DMI} / \mathrm{FCM}$ & $1.40^{\mathrm{d}}$ & $1.44^{\mathrm{d}}$ & $1.57^{\mathrm{c}}$ & $2.02^{\mathrm{b}}$ & $2.29^{\mathrm{a}}$ & 0.08 \\
\hline TDN/FCM & $0.95^{\mathrm{c}}$ & $0.95^{\mathrm{c}}$ & $1.03^{\mathrm{c}}$ & $1.25^{\mathrm{b}}$ & $1.39^{\mathrm{a}}$ & 0.04 \\
\hline DCP/FCM & $0.12^{\mathrm{c}}$ & $0.12^{\mathrm{c}}$ & $0.13^{c}$ & $0.17^{\mathrm{b}}$ & $0.20^{\mathrm{a}}$ & 0.01 \\
\hline
\end{tabular}


UFDDP; CFM3: concentrated feed mixture contains 35\% UFDDP; CFM4: concentrated feed mixture contains $17.5 \%$ corn grains plus $17.5 \%$ FDDP; CFM5: concentrated feed mixture contains $35 \%$ FDDP.

Table (6). Milk production and composition of lactating buffaloes fed experimental rations.

\begin{tabular}{lcccccc}
\hline Items & \multicolumn{5}{c}{ Experimental rations } & \\
\cline { 2 - 6 } & $\mathrm{R} 1$ & $\mathrm{R} 2$ & $\mathrm{R} 3$ & $\mathrm{R} 4$ & $\mathrm{R} 5$ & SEM \\
\hline Calculated 7\% fat milk ( FCM) & $11.75^{\mathrm{a}}$ & $11.37^{\mathrm{ab}}$ & $10.53^{\mathrm{b}}$ & $8.10^{\mathrm{c}}$ & $7.14^{\mathrm{c}}$ & 0.49 \\
Milk composition, \% & & & & & & \\
Fat & $7.45^{\mathrm{a}}$ & $6.92^{\mathrm{b}}$ & $6.62^{\mathrm{bc}}$ & $6.35^{\mathrm{c}}$ & $5.64^{\mathrm{d}}$ & 0.17 \\
Protein & $4.58^{\mathrm{a}}$ & $4.40^{\mathrm{b}}$ & $4.35^{\mathrm{bc}}$ & $4.26^{\mathrm{cd}}$ & $4.17^{\mathrm{d}}$ & 0.05 \\
Lactose & 5.00 & 5.30 & 5.49 & 5.38 & 5.16 & 0.45 \\
TS & $17.67^{\mathrm{a}}$ & $17.04^{\mathrm{b}}$ & $17.13^{\mathrm{b}}$ & $16.95^{\mathrm{b}}$ & $16.13^{\mathrm{c}}$ & 0.17 \\
\hline
\end{tabular}

$a, b, c$ and $d:$ means in the same row with different superscripts differ significantly.

Table (7). Economic efficiency of daily milk production.

\begin{tabular}{|c|c|c|c|c|c|c|}
\hline \multirow{2}{*}{ Items } & \multicolumn{5}{|c|}{ Experimental rations } & \multirow[b]{2}{*}{ SEM } \\
\hline & $\mathrm{R} 1$ & R2 & R3 & $\mathrm{R} 4$ & R5 & \\
\hline Milk price (L.E/day) & $52.88^{\mathrm{a}}$ & $51.17^{\mathrm{a}}$ & $47.39^{\mathrm{b}}$ & $36.45^{\mathrm{c}}$ & $32.13^{\mathrm{d}}$ & 1.29 \\
\hline Feed cost (L.E/day) & $25.9^{\mathrm{a}}$ & $24.3^{\mathrm{a}}$ & $23.50^{\text {cd }}$ & $24.14^{\mathrm{b}}$ & $22.7^{\mathrm{d}}$ & 0.24 \\
\hline Profit,( L.E) & 26.98 & 26.80 & 23.89 & 12.31 & 9.43 & \\
\hline Additional input** (L.E) & ------ & ------ & ------ & 6.69 & 12.48 & \\
\hline Total profit & 26.98 & 26.80 & 23.89 & 19 & 21.91 & \\
\hline Economic efficiency* & $2.04^{\mathrm{ab}}$ & $2.11^{\mathrm{a}}$ & $2.02^{\mathrm{ab}}$ & $1.79^{\mathrm{c}}$ & $1.97^{\mathrm{b}}$ & 0.05 \\
\hline
\end{tabular}

$a, b, c$ and $d:$ means in the same row with different superscripts differ significantly.

*Economic efficiency $=$ money input/money output

${ }^{* *}$ Additional input $=($ amount of ethanol produced $(l) \times 22.12)-$ cost of 1 letter ethanol produced .

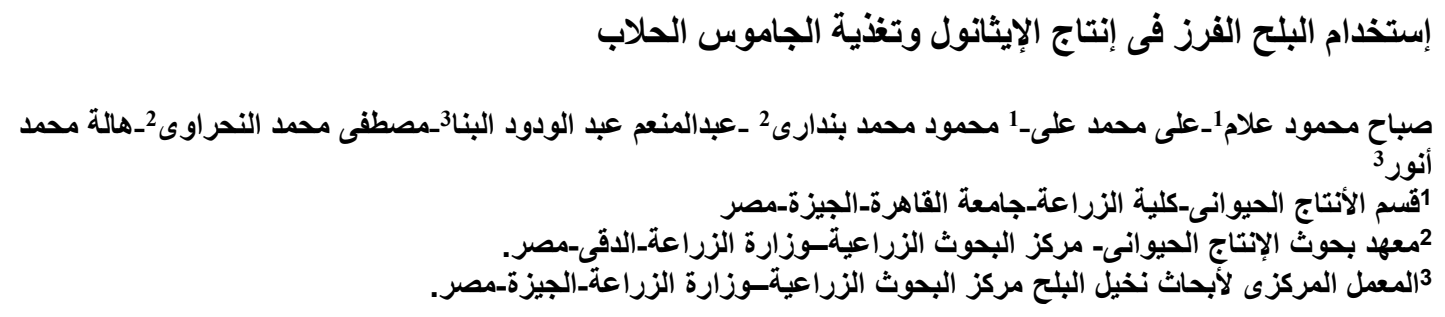

التقييم التركيب الكيماوى و القيمة الغذائية والكفاءة الغذائية والأقتصادية لإستخدام البلح الفرز فى علائق الجاموس الحلاب قبل وبعد إنتاج

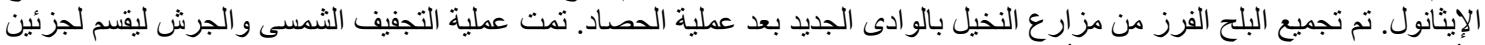

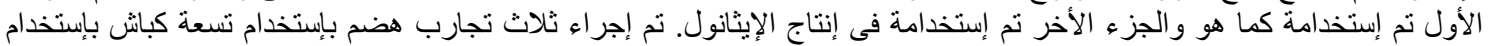

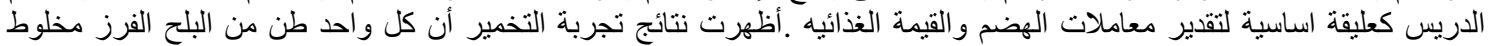

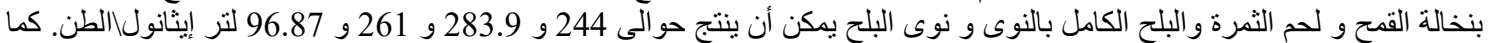

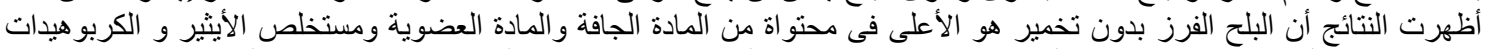

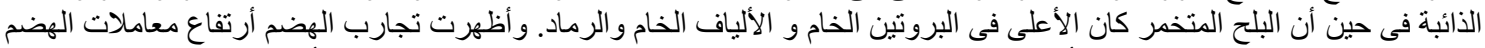

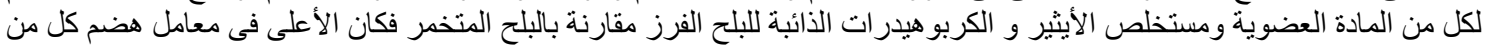

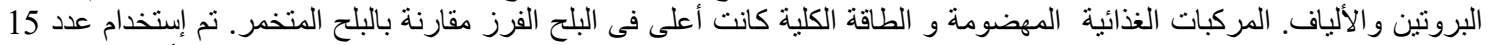

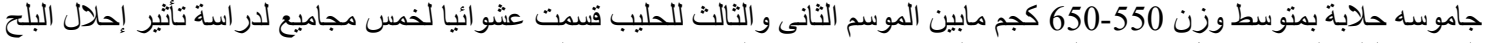

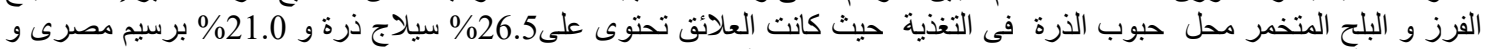

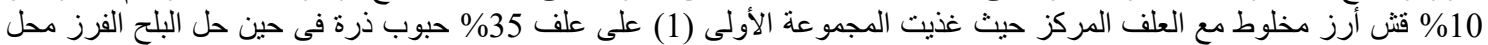

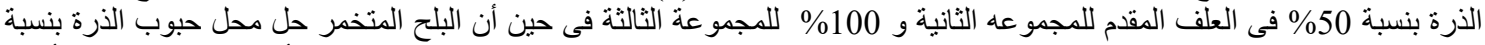

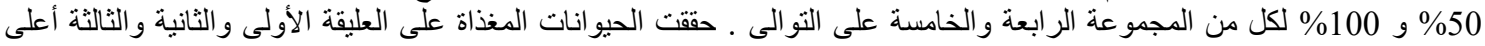

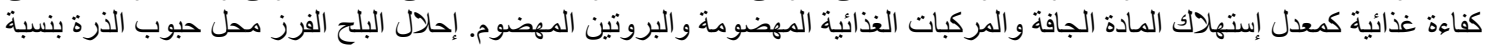

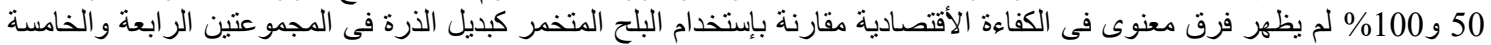

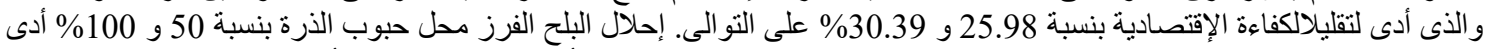

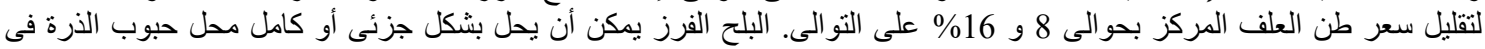

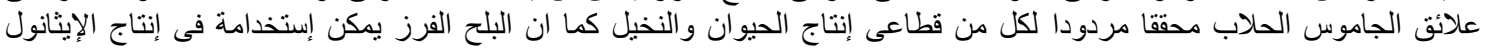
و إدراج المنتج الثنانوى كعلف صالح لتغذية الحيوان. 